\title{
Effect of Hypothermic Anoxic Arrest on Myocardial Contractility in the Isolated Blood-Perfused Canine Left Ventricular Muscle
}

\author{
Hiroshi Shida, M.D.* and Miyoharu Kobayashi, M.D.**
}

\begin{abstract}
SUMMARY
The present studies were performed to evaluate the protective effect of topical hypothermia on anoxic heart. The myocardial protection was assessed by myocardial contractility in the isolated blood-perfused electrically driven canine left ventricular muscle. The isometric tension and the rate of rise of tension development $(\mathrm{dT} / \mathrm{dt})$ were measured before and after hypothermic anoxic arrest and percent recovery of these values was used as a parameter of myocardial contractility. The percent recovery rates of $100,95,90$, and 65 were obtained after acute anoxia of $90,120,150$, and $180 \mathrm{~min}$, respectively at the myocardial temperature of $17^{\circ} \mathrm{C}$. These data suggest that the safe limit of acute anoxia at the myocardial temperature of $17^{\circ} \mathrm{C}$ is defined as $90 \mathrm{~min}$ in this experimental model and it can be extended to $120 \mathrm{~min}$ at the myocardial temperature below $17^{\circ} \mathrm{C}$.
\end{abstract}

\section{Additional Indexing Words :}

Myocardial protection Hypothermic anoxic arrest Myocardial contractility Isolated blood-perfused canine left ventricular muscle

CINGE Shumway, ${ }^{1)}$ Hurley, ${ }^{2 \prime}$ and Griepp ${ }^{3)}$ found that effective myocardial $D$ protection could be achieved by means of elective cardiac surface cooling by pericardial irrigation with cold $\left(4^{\circ} \mathrm{C}\right)$ physiological saline solution, topical hypothermia has been widely used clinically and a number of studies in which the significant protective effects of hypothermia on the anoxic heart were assesscd in morphologic, metabolic, and hemodynamic aspects have been reported. Hitherto, there have been several investigations to examine the recovery of myocardial contractility after acute anoxia ${ }^{4,5)}$ or the possible protection of cardiac muscle from the consequence of acute anoxia in the isolated cardiac muscle preparation. ${ }^{6)-81}$ However, there are few studies in which the myocardial contractility in the isolated blood-perfused cardiac muscle has been employed to assess the protective effect of hypothermia on

From the Second Department of Surgery* and the Department of Pharmacology**, Faculty of Medicine, Shinshu University, Matsumoto, Japan.

Address for reprint: H. Shida, M.D., Second Department of Surgery, Faculty of Medicine, Shinshu University, Asahi 3-1-1, Matsumoto 390, Japan.

Received for publication March 13, 1979. 
the anoxic cardiac muscle.9) Moreover, although several satisfactory preparations have been available for the investigation of acute anoxia in the isolated myocardial preparation, ${ }^{5,9}, 9$ the well-controlled, reproducible preparation for the studies of hypothermic anoxic arrest has been less easily achieved.

The purpose of this paper is to describe a simple, yet controlled preparation for the assessment of the possible effect of hypothermic anoxic arrest on the myocardial contractility and also to investigate an interrelation between the optimal myocardial temperature and the safe duration of anoxic arrest in this experimental model.

\section{Methods}

The experimental preparation consists of isolated canine left ventricular muscle perfused with blood according to the technique described by Chiba. ${ }^{10}$ The mongrel dogs of both sexes weighing 8 to $15 \mathrm{Kg}$ were anesthetized with intravenous administration of $30 \mathrm{mg} / \mathrm{Kg}$ of pentobarbital and heparinized with $1 \mathrm{mg} /$ $\mathrm{Kg}$ of heparin, and the heart was removed. A part of the left ventricular muscle along the anterior descending branch of the left coronary artery was quickly excised and bathed into cold Tyrode's solution. The wet weight of the excised muscle was approximately 10 to $15 \mathrm{Gm}$. The left anterior descending artery was cannulated with a small polyethylene catheter and perfused with arterial blood led from a carotid artery of the support dog at a constant rate of $8.4 \mathrm{ml} / \mathrm{ml}$ by means of a Havard pump. A pneumatic resistance was placed in parallel with the perfusion system to obtain a constant pressure of $100 \mathrm{mmHg}$. The isolated bloodperfused left ventricular muscle was suspended in a cup-shaped glass container, which was maintained at a constant temperature of $37^{\circ} \mathrm{C}$, with the two parts of the muscle fixed to a stainless steel bar. The upper part of the isolated ventricular muscle was attached by a silk thread to a force-displacement transducer (Nihon Koden SB-1TA). The volume of the container was $65 \mathrm{ml}$ and was initially filled with warmed Tyrode's solution, which was gradually displaced by the blood leaving the isolated ventricular muscle. Two streams of blood, overflowing from the container and passing through the pneumatic resistance, were collected in a blood reservoir and then returned to the support dog through a jugular vein. The muscle was electrically paced at a rate of $70 / \mathrm{min}$ with current of $3 \mathrm{~mA}$. The muscle was loaded with a resting tension of $2 \mathrm{Gm}$. The isometric tension and the rate of rise of tension development $(\mathrm{dT} / \mathrm{dt})$ were continuously recorded on an ink-writing rectigraph (Nihon Kohden WI-680G) through a carrier amplifier (Nihon Kohden AP-600G) and an electronic differentiator (Nihon Kohden ED-600G). The diagram of the blood-perfused system of the canine left ventricular myocardium is shown in Fig. 1.

In the present studies, coronary perfusion was stopped and the isolated ventricular muscle was bathed in Tyrode's solution at $17^{\circ} \mathrm{C}$ while anoxic time was varied from $90 \mathrm{~min}$ to $180 \mathrm{~min}$. The myocardial temperature rapidly equilibrated with the temperature of the cold Tyrode's solution in which the muscle was bathed. After each anoxic period the muscle was reperfused with arterial blood from the support dog until the myocardial contractility fully recovered at the myocardial 


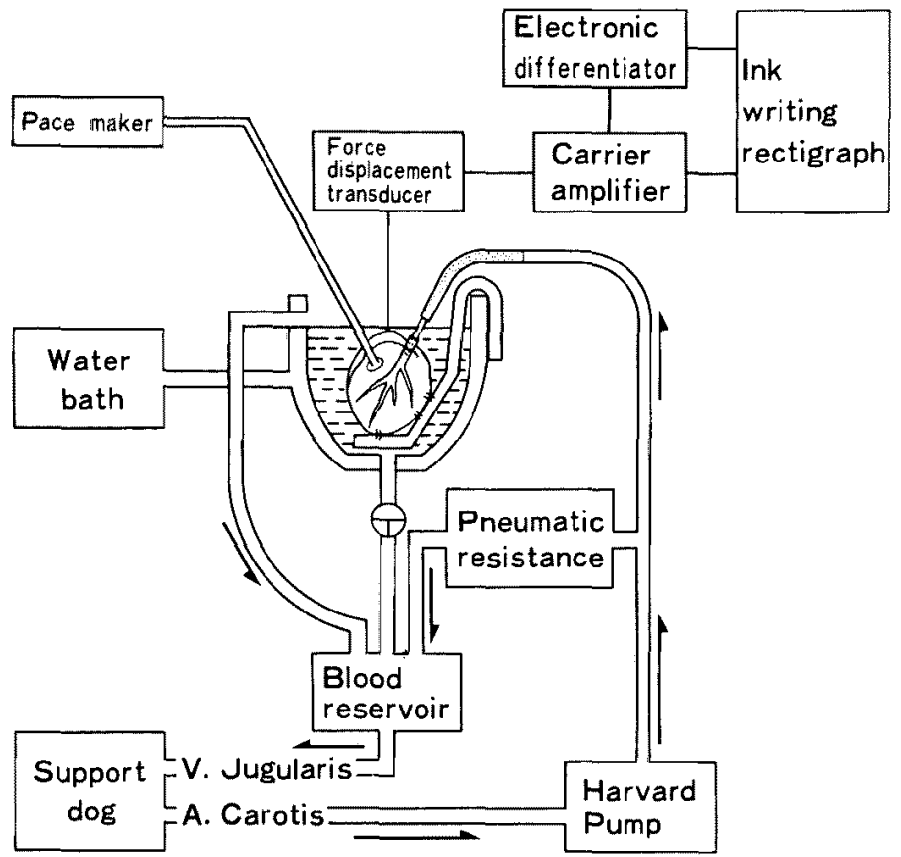

Fig. 1. Schematic presentation of the perfusion of the isolated canine left ventricular muscle with blood led from the carotid artery of support dog.

temperature of $37^{\circ} \mathrm{C}$. The maximal developed tension at this point was referred to as a percent recovery in comparison with the maximal tension before anoxic arrest. Arterial $\mathrm{PO}_{2}, \mathrm{PCO}_{2}$, base excess, and $\mathrm{pH}$ of the support dog were measured at intervals using a blood gas analyzer. These values were maintained within normal range by the addition of oxygen and by the administration of $7 \%$ sodium bicarbonate solution.

\section{Results}

As soon as the isolated ventricular muscle was prepared and perfused with the arterial blood of the support dog, the muscle started to contract with a slow rhythm followed by ventricular fibrillation. Approximately $20 \mathrm{~min}$ after the start of perfusion the muscle showed a good response to electical pacing and the net developed tension defined as total developed tension minus resting tension continued to increase. Approximately $90 \mathrm{~min}$ was required before the maximal net developed tension reached a plateau, and the postischemic recovery time required to obtain a plateau of the maximal net developed tension was approximately $60 \mathrm{~min}$.

In the control group the net developed tension showed a plateau at the termination of 4 hours of continuous coronary perfusion. In the experimental 


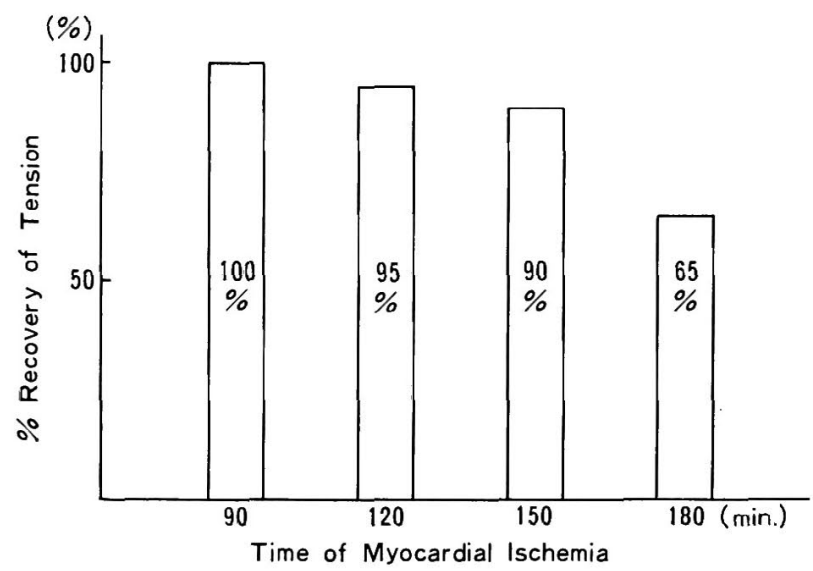

Fig. 2. The interrelation between the percent recovery rate of maximal net developed tension and various anoxic time at the myocardial temperature of $17^{\circ} \mathrm{C}$.

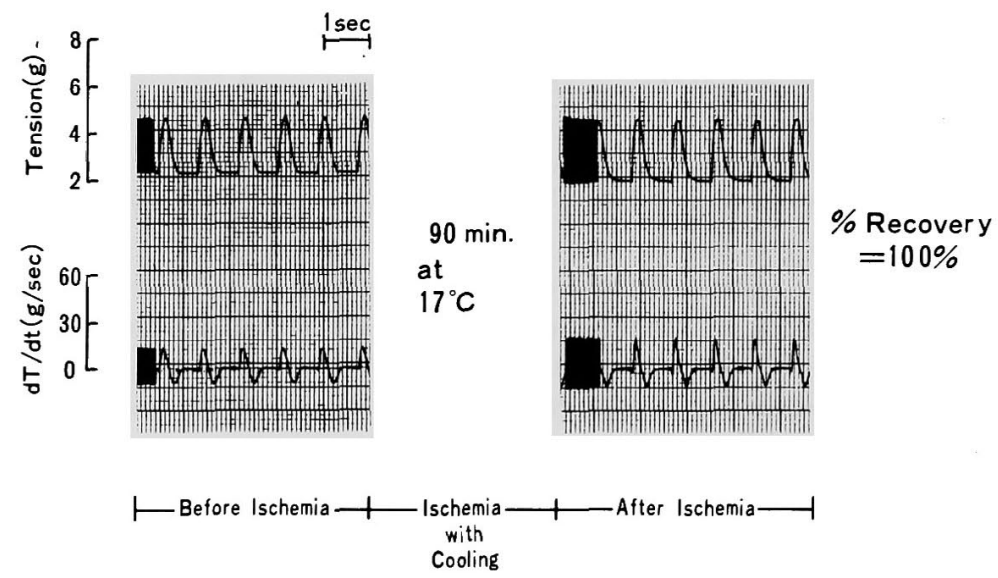

Fig. 3. This rectigram shows the change of the maximal net developed tension and the rate of rise of tension development $(\mathrm{dT} / \mathrm{dt})$ before and after acute anoxia of $90 \mathrm{~min}$ at the myocardial temperature of $17^{\circ} \mathrm{C}$, indicating the percent recovery rate of 100 .

groups of anoxic arrest time of 45 and $60 \mathrm{~min}$ at the myocardial temperature of $37^{\circ} \mathrm{C}$, the percent recovery rates of the net developed tension were $70 \pm 5 \%$ (mean $\pm \mathrm{SD}, \mathrm{n}=5$ ) and $30 \pm 3 \%(\mathrm{n}=5)$ respectively. In the experimental groups of hypothermic anoxic arrest time of 90,120, 150, and $180 \mathrm{~min}$ at the myocardial temperature of $17^{\circ} \mathrm{C}$, as shown in Fig. 2, the percent recovery rates of the net developed tension were $100 \%(n=3), 95 \pm 3 \%(n=5), 90 \pm 5 \%$ $(n=5)$, and $65 \pm 5 \%(n=5)$, respectively. Fig. 3 shows a record of the case presenting the percent recovery of the net developed tension and $d T / d t$ of 
Table I. Blood Gas Analysis in Support Dog

\begin{tabular}{l|c|c}
\hline & Before Ischemia & After Ischemia \\
\hline $\mathrm{pH}$ & $7.355 \pm 0.087$ & $7.340 \pm 0.082$ \\
B.E. $(\mathrm{mEq})$ & $-8.0 \pm 3.3$ & $-7.8 \pm 3.4$ \\
$\mathrm{PaCO}_{2}(\mathrm{mmHg})$ & $30 \pm 9$ & $31 \pm 7$ \\
$\mathrm{PaO}_{2}(\mathrm{mmHg})$ & $96 \pm 11$ & $\mathrm{NS}$ \\
& & $\mathrm{NS} \pm 23$ \\
\end{tabular}

Values are mean $\pm \mathrm{SD}, \mathrm{NS}=$ no statistical significance.

$100 \%$ in the anoxic time of $90 \mathrm{~min}$ at the myocardial temperature of $17^{\circ} \mathrm{C}$. Through the experiments the change of the rate of rise of tension development $(\mathrm{dT} / \mathrm{dt}$ ) showed a parallel relation to that of the maximal net developed tension.

On the studies of acid-base change in the support dogs, as shown in Table I, there was no significant differences between arterial $\mathrm{pH}$, base excess, $\mathrm{PCO}_{2}$, and $\mathrm{PO}_{2}$ during the preischemic perfusion and those during the postischemic perfusion, because these values were maintained within normal ranges by the addition of oxygen and by the administration of sodium bicarbonate. In such a condition of acid-base balance in the support dogs, as shown in Fig. 4, the percent recovery rate of the maximal net developed tension following acute anoxia of $150 \mathrm{~min}$ at the myocardial temperature of $17^{\circ} \mathrm{C}$ was approximately 90 . While in metabolic acidosis of the support dog during the postischemic perfusion, as shown in Fig. 5, the percent recovery of the

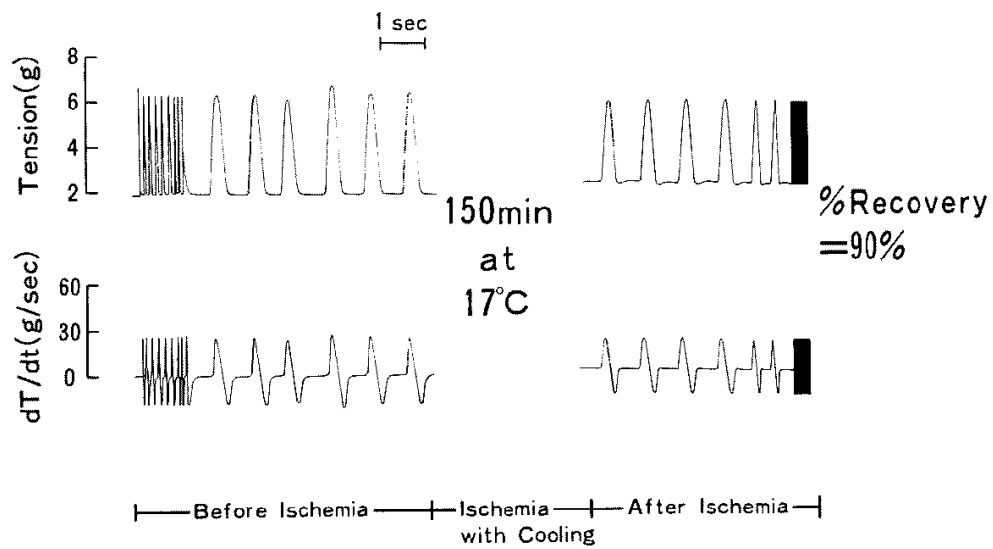

Fig. 4. This rectigram shows the change of the maximal net developed tension and $\mathrm{dT} / \mathrm{dt}$ before and after acute anoxia of $150 \mathrm{~min}$ at the myocardial temperature of $17^{\circ} \mathrm{C}$, indicating the percent recovery rate of 90 . 




Fig. 5. This rectigram shows an influence of metabolic acidosis on myocardial contractility. In metabolic acidosis of the support dog during postischemic perfusion the percent recovery rate of the maximal net developed tension and $\mathrm{dT} / \mathrm{dt}$ following the same hypothermic anoxic arrest were reduced to 50 .

maximal net developed tension following the same hypothermic anoxic arrest was reduced to 50 .

\section{Discussion}

The effect of hypothermic anoxic arrest on left ventricular function has been experimentally evaluated by means of isovolumetric contractility using a latex balloon in canine whole heart supported by cardiopulmonary bypass, ${ }^{11}$ aortic flow rate by Langendorff's preparation, ${ }^{12)}$ and myocardial contractility in isolated cardiac preparation.9" The measurement of isovolumetric contractility of the left ventricle using a latex balloon and aortic pressure or flow rate by Langendorff's preparation were noted to be technically complicated and associated with many uncontrolled variables as mentioned by Ino.9) An alternative to evaluate the left ventricular function after acute anoxia is to measure myocardial contractility. There have been a number of investigations along these lines, however much of this work can be criticized on methodological grounds. In some experiments isolated whole heart preparations have been used with the associated problem of adequate oxygenation in the control state, ${ }^{4), 7), 14)}$ while the use of isolated spontaneously beating atrial preparation is complicated by the interrelation between rate and myocardial 
contractile force. ${ }^{8), 13,15)}$ A papillary muscle preparation has been widely employed to examine the mechanism of myocardial contractility, ${ }^{5), 6(16), 17}$ however, such an excised nonperfused papillary muscle preparation could not be used in the present hypothermic anoxic experiment, because normothermic coronary perfusion is required before and after hypothermic anoxic arrest. Ino ${ }^{91}$ demonstrated a unique method using isolated, blood-perfused and spontaneously beating rabbit papillary muscle preparation to evaluate myocardial contractility after hypothermic anoxic cardioplegia. It is known that the strength of contraction of isolated cardiac muscle is influenced by the frequency of contraction, ${ }^{18)}$ Therefore, it is important to use an electrically driven muscle preparation. ${ }^{19}$ ) Recently, Shine ${ }^{20)}$ reported that isolated blood-perfused electrically driven rabbit interventricular septa could be adapted for studies of global ischemia by enclosure in a constant-humidity nitrogen atmosphere. The experimental model described here has several characteristics. Namely, the isolated electrically driven left ventricular muscle is perfused with arterial blood led from a carotid artery of the support dog and the myocardial contractility can be precisely measured with stable contractility over 4 hours. The coronary perfusion through the cannulated anterior descending artery of the isolated left ventricular muscle can be precisely regulated. In addition, the temperature of the ventricular muscle suspended in the glass-container filled by blood leaving the isolated blood-perfused muscle or Tyrode's solution can be quickly regulated by circulating water pumped from a water bath. The same preparation can be used for studies of metabolic changes and evaluation of cardioplegic solutions.

A controversy exists on the optimal myocardial temperature for the application of topical cardiac hypothermia in cardiac surgery. Shumway ${ }^{11}$ and Griepp $^{3 /}$ have advocated maintenance of the intramyocardial temperature between 15 to $20^{\circ} \mathrm{G}$ providing satisfactory myocardial protection in clinical use. In experimental studies Angell21) reported that anoxic time of $180 \mathrm{~min}$ at the myocardial temperature of $15^{\circ} \mathrm{C}$ allowed the viability of canine cadaver heart and Ino $^{1 /}$ also noted that the optimal myocardial temperature for satisfactory myocardial protection was $18^{\circ} \mathrm{C}$. In our clinical experience the topical cardiac surface cooling with cold $\left(4^{\circ} \mathrm{C}\right)$ lactated Ringer's solution and ice slush resulted in the maintenance of intramyocardial temperature of $17^{\circ} \mathrm{C}$. Therefore, in the present studies the myocardial temperature of $17^{\circ} \mathrm{C}$ was chosen as an optimal level of hypothermia.

In the study of a correlation between myocardial temperature and left ventricular function, Greenberg ${ }^{22}$ found that less than $30 \%$ depression of left ventricular function occurred after acute anoxia of $10 \mathrm{~min}$ at $37^{\circ} \mathrm{C}, 15$ $\min$ at $28^{\circ} \mathrm{C}, 30 \mathrm{~min}$ at $18^{\circ} \mathrm{C}$, and pronounced depression occurred after 30 
$\min$ at $37^{\circ} \mathrm{C}$. Angell ${ }^{11)}$ also reported that the maximum intervals of allowable anoxia were $35 \mathrm{~min}$ at $37^{\circ} \mathrm{C}, 115 \mathrm{~min}$ at $24^{\circ} \mathrm{C}$, and $230 \mathrm{~min}$ at $15^{\circ} \mathrm{C}$ in canine heart. Ino $\left.{ }^{9}\right)$ and associates showed the significant protective effect of hypothermia on the anoxic heart. They found that $80 \%$ recovery of myocardial contractility was estimated after anoxic arrest of $150 \mathrm{~min}$ at $18^{\circ} \mathrm{C}$ from the nomogram expressing anoxic time, myocardial temperature, and percentage recovery of papillary muscle contractility after reperfusion and suggested that the nomogram constructed from rabbit heart experiments could be applied to human beings. The present studies showed that $100 \%, 95 \%, 90 \%$, and $65 \%$ recovery of myocardial contractility after reperfusion at myocardial temperature of $17^{\circ} \mathrm{C}$ were obtained after anoxic arrest of $90 \mathrm{~min}, 120 \mathrm{~min}$, $150 \mathrm{~min}$, and $180 \mathrm{~min}$, respectively, while $70 \%$ and $30 \%$ recovery at $37^{\circ} \mathrm{C}$ were obtained after anoxic arrest of $45 \mathrm{~min}$ and $60 \mathrm{~min}$, indicating a significant protective effect of hypothermia on the anoxic cardiac muscle.

The safe duration of myocardial anoxia for human beings using topical heart cooling has not been clearly defined. It has been reported that the time limit of safe cardioplegia is as long as $30 \mathrm{~min}$ by Willman, ${ }^{23)} 45 \mathrm{~min}$ by Sprovieri, ${ }^{24)} 60 \mathrm{~min}$ by Heimbecker, ${ }^{25)}$ up to $70 \mathrm{~min}$ by Robicsek, ${ }^{26)} 71 \mathrm{~min}$ by Urschel, ${ }^{27)} 90 \mathrm{~min}$ by Griepp, ${ }^{31}$ and $128 \mathrm{~min}$ by Pupello. ${ }^{28)}$ According to Ino, ${ }^{9}$ maximal tolerable anoxic period can be prolonged to nine times of the control by cooling the heart at $18^{\circ} \mathrm{C}$. On the bases of the present experimental experience, the safe duration of hypothermic anoxic arrest is as long as $90 \mathrm{~min}$, and it can be even further extended up to $120 \mathrm{~min}$.

It is well documented that myocardial performance is impaired by acidosis. Initially, it was suggested that extracellular $\mathrm{pH}$ was the principal determinant of cardiac performance ${ }^{29}$ but recently the importance of intracellular $\mathrm{pH}$ has been recognized. ${ }^{30)-32}$ Moreover, a more remarkable decrease in intracellular $\mathrm{pH}$ was noted during respiratory acidosis produced by the increase of $\mathrm{PaCO}_{2}$ than during metabolic acidosis produced by the decrease of bicarbonate concentration. Several investigators also state that intracellular $\mathrm{pH}$ is an important determinant of myocardial contractility, because metabolic acidosis results in a smaller negative inotropic effect than respiratory acidosis at the same extracellular $\mathrm{pH}^{321-34)}$ In the present studies, a remarked metabolic acidosis caused a significant decrease of myocardial contractility. Therefore, arterial $\mathrm{pH}, \mathrm{PCO}_{z}$, and base excess of the support dog were maintained within normal ranges by the addition of oxygen and the administration of sodium bicarbonate throughout the experiment.

Conclusively, the experimental model described here has several characteristics and can be used for evaluation of the effect of hypothermic anoxic arrest on myocardial contractility. In this experimental model topical hypo- 
thermia itself proves to be an effective method for protection against myocardial damage after acute anoxia. Myocardial temperature of $17^{\circ} \mathrm{C}$ allows anoxic arrest of jup to $90 \mathrm{~min}$ with safety and the safe limit can be extended to up to $120 \mathrm{~min}$ with the recovery of $95 \%$ in myocardial contractility.

\section{REFERENCES}

1. Shumway NE, Lower RR: Topical cardiac hypothermia for extended periods of anoxic arrest. Surg Forum 10: 563, 1960

2. Hurley EJ, Lower RR, Dong E Jr, Pillsbury RG, Shumway NE: Clinical experience with local hypothermia in elective cardiac arrest. J Thorac Cardiovasc Surg 47: 50, 1964

3. Griepp RB, Stinson EB, Shumway NE: Profound local hypothermia for myocardial protection during open-heart surgery. J Thorac Cardiovasc Surg 66: 731, 1973

4. Penn RG: Some factors influencing the recovery of isolated myocardium from acute anoxia. Brit J Pharmacol 24: 253, 1965

5. Tyberg JV, Yeatman LA, Parmley WW, Urschel CW, Sonnenblick EH: Effect of hypoxia on mechanics of cardiac contraction. Am J Physiol 218: 1780, 1970

6. Winbury MM: Influence of glucose on contractile activity of papillary muscle during and after anoxia. Am J Physiol 187: 135, 1956

7. Setnikar I, Ravasi MT: Increase in resistance of the heart to anoxia by iproniazid. Arch int Pharmacodyn 124: 116, 1960

8. McInnes L, Parratt JR: Studies on the mode of action of hexobendine a prospective antianginal drug. Brit J Pharmacol 37: 272, 1969

9. Ino $T$, Wakabayashi $A$, Guilmette $\mathrm{JE} J \mathrm{~J}$, Shinto RA, Connolly $\mathrm{JE}$ : Effect of hypothermic anoxic cardioplegia on myocardial contractility. Ann Surg 22: 424, 1976

10. Chiba, S: Effect of verapamil on frequency-force relationship in isolated dog left ventricular muscle. Jap J Pharmacol 27: 175, 1977

11. Follette D, Fey K, Mulder D, Maloney JV, Buckberg GD: Prolonged safe aortic clamping by combining membrane stabilization, multidose cardioplegia, and appropriate $\mathrm{pH}$ reperfusion. J Thorac Cardiovasc Surg 74: 682, 1977

12. Hearse DJ, Stewart DA, Chain EB: Recovery from cardiac bypass and elective cardiac arrest. Circulat Res 35: 448, 1974

13. Penn RG: The effect of age, species and adrenaline on the recovery of isolated atria from anoxia. Brit J Pharmacol 39: 309, 1970

14. Hopkins SV: The potentiation of the action of adenosine on the guinea-pig heart. Biochem Parmac 22: 341, 1973

15. Gardner EA, Farah A: The action of some enzyme inhibitors on the isolated rabbit auricle. J Pharm exp Ther $111: 225,1954$

16. Sonnenblick EH: Force-velocity relations in mammalian heart muscle. Am J Physiol 205: 931,1962

17. Bing OHL, Keefe JF, Wolk MJ, Finkelstein LJ, Levine HJ: Tension prolongation during recovery from myocardial hypoxia. J Clin Invest 50:660, 1971

18. Koch-Weser J, Blinks JR: The influence of the interval between beats on myocardial contractility. Pharmacol Rev 15:601, 1963

19. Parratt $J R$, Marshall $\mathrm{RJ}$ : The response of isolated cardiac muscle to acute anoxia: protective effect of adenosine triphosphate and creatin phosphate. J Pharm Pharmac 26: 427, 1974

20. Shine KI, Douglas AM, Ricchiuti N: Ischemia in isolated interventricular septa: mechanical events. Am J Physiol 231: 1225, 1976

21. Angell WW, Rikkers L, Dong E Jr, Shumway NE: Organ viability with hypothermia. 
J Thorac Cardiovasc Surg 58: 619, 1969

22. Greenberg JJ, Edmunds LH: Effect of myocardial ischemia at varying temperatures on left ventricular function and tissue oxygen tension. J Thorac Cardiovasc Surg 42: 84, 1961

23. Willman VL, Howard HS, Cooper T, Hanlon CR: Ventricular function after hypothermic cardiac arrest. Arch Surg 82: 120, 1961

24. Sprovieri L, Blondeau P, Piwnica A, Baculard P, Dubost C: Coronary perfusion in the surgery of the aortic valve. J Cardiovasc Surg 6: I, 1965

25. Heimbecker RO, Lajos TZ: Ice-chip cardioplegia. Arch Surg 84: 148, 1962

26. Robicsek F, Tam W, Daugherty HK, Mullen DC: Myocardial protection during open-heart surgery. Ann Thorac Surg 10: 340,1970

27. Urschel HC Jr, Greenberg JJ: Diflerential cardiac hypothermia for elective cardioplegia. Ann Surg 152: 845, 1960

28. Pupello DF, Blank RH, Connar RG, Bessone LN, Sbar S, Stevenson A: Fifty-two consecutive aortic valve replacements employing local deep hypothermia. Ann Thorac Surg 19: 487,1975

29. McElroy WT Jr, Gerdes AJ, Brown EB: Effects of $\mathrm{CO}_{2}$, bicarbonate and $\mathrm{pH}$ on the performance of isolated perfused guinea pig hearts. Am J Physiol 195: 412, 1958

30. Ng ML, Levy MN, Zieske HA : Effects of changes of $\mathrm{pH}$ and of carbon dioxide tension on left ventricular performance. Am J Physiol 213: 115, 1967

31. Clancy RL, Gingolani HE, Taylor RR, Graham TP Jr, Gilmore JP: Influence of sodium bicarbonate on myocardial performance. Am J Physiol 212: 917, 1967

32. Cingolani HE, Mattiazzi AR, Blesa ES, Gonzalez NC: Contractility in isolated mammalian heart muscle after acid-base changes. Circulat Res 26: 269, 1970

33. Williamson JR, Safer B, Rich T, Schaffer S, Kobayashi K: Effects of acidosis on myocardial contractility and metabolism. Acta Med Scand 587: 95, 1975

34. Steenbergen G, Deleeuw G, Rich T, Williamson JR: Effect of acidosis and ischemia on contractility and intracellular $\mathrm{pH}$ of rat heart. Circulat Res 41: 849, 1977 